IZA DP No. 4847

Does Education Reduce the Risk of Hypertension? Estimating the Biomarker Effect of Compulsory Schooling in England

Nattavudh Powdthavee

March 2010 


\title{
Does Education Reduce the Risk of Hypertension? Estimating the Biomarker Effect of Compulsory Schooling in England
}

\author{
Nattavudh Powdthavee \\ University of York \\ and IZA
}

Discussion Paper No. 4847

March 2010

IZA

P.O. Box 7240

53072 Bonn

Germany

Phone: +49-228-3894-0

Fax: +49-228-3894-180

E-mail: iza@iza.org

Any opinions expressed here are those of the author(s) and not those of IZA. Research published in this series may include views on policy, but the institute itself takes no institutional policy positions.

The Institute for the Study of Labor (IZA) in Bonn is a local and virtual international research center and a place of communication between science, politics and business. IZA is an independent nonprofit organization supported by Deutsche Post Foundation. The center is associated with the University of Bonn and offers a stimulating research environment through its international network, workshops and conferences, data service, project support, research visits and doctoral program. IZA engages in (i) original and internationally competitive research in all fields of labor economics, (ii) development of policy concepts, and (iii) dissemination of research results and concepts to the interested public.

IZA Discussion Papers often represent preliminary work and are circulated to encourage discussion. Citation of such a paper should account for its provisional character. A revised version may be available directly from the author. 
IZA Discussion Paper No. 4847

March 2010

\section{ABSTRACT \\ Does Education Reduce the Risk of Hypertension? Estimating the Biomarker Effect of Compulsory Schooling in England ${ }^{*}$}

This paper estimates the exogenous effect of schooling on reduced incidence of hypertension. Using the changes in the minimum school-leaving age law in the United Kingdom from age 14 to 15 in 1947, and from age 15 to 16 in 1973, as sources of exogenous variation in schooling, the regression discontinuity and IV-probit estimates imply that completing an extra year of schooling reduces the probability of developing subsequent hypertension by approximately $7-12 \%$ points; the result which holds only for men and not for women. The correct IV-probit estimates of the LATE for schooling indicate the presence of a large and negative bias in the probit estimates of schooling-hypertension relationship for the male subsample.

JEL Classification: $\quad H 1, I 1, I 2$

Keywords: hypertension, compulsory schooling, biomarker, regression discontinuity, health

Corresponding author:

Nattavudh Powdthavee

Department of Economics \& Related Studies

University of York

Heslington

York YO10 5DD

Great Britain

E-mail: np517@york.ac.uk

\footnotetext{
* I am thankful to Andrew Oswald, Hendrik Jürges, and two anonymous referees for the helpful comments. Usual disclaimers apply.
} 
Ever since Michael Grossman's seminal work on the demand for health in the early 1970s (Grossman, 1972; and subsequently, Grossman, 2000; 2005), researchers have routinely tried to estimate the effects of different socio-economic variables on a variety of health outcomes. So far, years of schooling has stood out as one of the statistically significant determinants of health. This is true whether health levels are measured by self-assessed health status, mortality rates, risky health behaviors, morbidity, physiological measures, and mental wellbeing (Grossman, 1975; Berger and Leigh, 1989; Kenkel, 1991; Deaton and Paxson, 2001; Oreopoulos, 2007; Blanchflower and Oswald, 2008).

There are, however, two major practical problems associated with the estimation of the schooling effect on health. The first corresponds to the classic estimation bias associated with ordinary least squares (OLS) estimates of the return to schooling. In the economics literature, researchers frequently use the instrumental variables (IV) approach to address the endogeneity of schooling decisions. A valid instrumental variable, which determines whether an individual receives more years of schooling, but does not determine other factors that affect the outcome of interest, can overcome estimation biases that often arise when using the OLS method. Yet, according to Guido Imbens and Joshua D. Angrist (1994) and Philip Oreopoulos (2006), many of the instruments used in the return to schooling literature - e.g., distance from home to college (Card, 1995), restrictive compulsory schooling law (Angrist and Krueger, 1991), and regional spending on education in regions where the individual was still a student (Berger and Leigh, 1989) - only affect a small fraction of the general population. As a result, many of the IV estimates produced in the literature are only approximations of the average treatment effects among a small group of people who happened to be exposed to the instruments (Card, 2001).

The second practical problem concerns the existing measures of health outcomes frequently used in the studies conducted by economists concerning the determinants of health. While there are valid reasons for using self-assessed health, mortality rates, morbidity, and risky health behaviors such as smoking and drinking as proxies for health, these variables can only, at best, be considered by the medical professions as indirect indicators of someone's underlying health. They do not, for example, possess the same clinical properties as such biomarkers as blood pressure, cortisol levels, cholesterol levels, or heart rate, which are normally used by clinicians to measure someone's biologic state. For example, selfreported health, which is the most commonly used measure of health outcomes in economics, is subject to a variety of potential measurement biases and interpersonal comparability problems (for a recent review, see Powdthavee, 2009). The same holds true for other self- 
reported health problems. Mortality rates, morbidity, and disability index may fair better as measures of health, given that each has the required quality of being 'objective'. Yet both are indicators of the extreme cases of ill-health and physical disablement, which will reflect only a small fraction of the nation's population. Because nationally representative surveys that contain both biomarker readings and years of schooling are scarce, econometric evidence on the biomarker effect of schooling is virtually non-existent.

This paper aims to fill that research void by using the unique Health Survey for England data set, which combines both interviews and physical examinations, to study the effects of schooling on adult hypertension readings in England. Following Harmon and Walker (1995), Oreopoulos (2006, 2007) and Devereux and Hart (2010), I will rely on exogenous changes in the amount of schooling received by individuals caused by the raising of the minimum school-leaving age in the United Kingdom (which has occurred twice over the age-spread of those over the age of 16 in the English data set). Because the changes of minimum school-leaving age affected a large fraction of people who would have left school at an earlier age before both reforms, IV-probit estimates of the schooling effects on the risk of hypertension is likely to come close to the average treatment effects that apply to the whole population (see Oreopoulos, 2006). In addition to the IV-probit approach, I also follow previous literature on compulsory schooling and adopt a regression discontinuity (RD) approach in order to illustrate the average educational attainment and adult hypertension just before and after the introduction of the two minimum school-leaving age laws.

There are empirically good reasons to use a zero-one indication of hypertension as the main biomarker for the nation's underlying health and well-being. Hypertension has been shown in the medical literature as the single most important predictor of heart disease and death from heart disease (Hofman, Feinleib, Garrison, and van Laar, 1981; Fraser, 1986; Wilson and colleagues, 1998), which is also the current biggest killer in America and the UK. Hypertension has also been used as a biomarker for stress and general psychological wellbeing in the work by David Blanchflower and Andrew J. Oswald (2008, 2009).

Section I gives an account of previous empirical evidence on the effects of schooling on health. Data and empirical strategy are discussed in Section II. Section III presents both $\mathrm{RD}$ and IV-probit results. Section IV concludes.

\section{Previous evidence on schooling and health outcomes}


Much of the previous attempts to estimate the effect of schooling on health outcomes have used measures of self-reported health as proxies for individual's health stock. Using a nationally representative American data set, Grossman (1972) is one of the first to document positive correlations between year of schooling and subjective health. Wagstaff (1986) employs the 1976 Danish data to show that schooling is positively correlated with a measure of good health indicated by having low combined scores of such self-reported health problems as physical mobility, respiratory problems and presence of pain. Erbsland, Reid, and Ulrich (1995) find similar relationships between schooling and self-reported health problems in a nationally representative German data set. Using a 1993 Dutch data set of men and women who were sixth grade pupils in 1953 in the province of Noord-Brabant, Hartog and Oosterbeek (1998) show that schooling have a positive relationship with self-rated health, even after controlling for IQ and parents' schooling among other variables. Gerdtham and Johannesson (1999) obtain similar findings in their subjective health equation using the 1991 Swedish micro data. More recently, Case, Fertig, and Paxson (2005) use the 1958 British National Child Development Study to show that self-reported health of males at age 42 is significantly correlated with the number of years completed formal schooling. The schooling coefficient is positive and statistically significant even in models that include selfrated health at age 23 and 33. For a more extensive review on the relationship between schooling and subjective health, see Grossman (2005).

There have also been attempts by economists to link the effects of schooling on other more objective health outcomes such as obesity and mortality. For example, Chou, Grossman, and Saffer (2004) find using the American Behavioral Risk Factor Surveillance System that schooling has a negative and statistically well-defined relationship with adult obesity. With respect to mortality, Grossman (1975) shows schooling to have a positive and statistically significant effect on the probability of survival for the middle-age white males in the NBER-Thorndike sample. More recently, Deaton and Paxson (2001) conclude using two American data sets that schooling has a negative effect on mortality for persons under the age of 60 as well as for person above that age.

Moreover, there is also some evidence of the beneficial effects of schooling on health behaviors. Using data from the Health Promotion/Disease Prevention Supplement to the 1995 National Health Interview Survey, Kenkel (1991) demonstrates schooling to have a negative and significant relationship with smoking and heavy drinking. Goldman and Smith (2002) find that more educated HIV/AIDS patients are more likely to adhere to therapy than their less educated counterpart. Similarly, de Walque (2007) finds that an increase in the level of 
exposition about the dangers of the HIV/AIDS epidemic supplied by the prevention programs in Uganda in 1990 has resulted in a significant drop in the risk of being HIV positive among young individuals in 2000.

Schooling is unlikely, however, to be exogenous. There are a variety of sources of bias associated with estimation of the schooling effect on health. First, causality may also run in reverse from health to schooling, i.e. healthier students may be more efficient producers of additional human capital via more years of formal schooling, which implies that estimates of the schooling effect on health will be biased upward. Second, there may be omitted third variables such as ability (Angrist and Kruger, 2001; Card, 2001), heritable endowments (Behrman and Rosenzweig, 2002), and time-preference (Fuch, 1982) that influence both schooling and health outcomes. One could imagine, for example, that people who are more future oriented (i.e. those who desire more leisure at older ages) will stay in school for longer, work more at younger ages, as well as have higher levels of health during most stages of the life cycle. Thus, the effect of schooling will be biased upward if one fails to control for timepreference. A third source of potential bias is measurement error, which can bias the estimated schooling effect toward zero (Blackburn and Neumark, 1995).

Previous work on the estimation of the schooling effect on health has mainly dealt with the endogeneity issue using either the IV method or the quasi-experimental approach, and the results have been mixed. Using the state of residence in childhood as instruments for schooling, Leigh and Dhir (1997) find schooling to be negatively related to an index of disability. However, there is little difference in size of the schooling coefficient whether it is treated as exogenous or endogenous. The same IV method is used by Sander (1995) to estimate the causal effect of schooling on smoking in the 1986-1991 National Opinion Research Center's General Social Survey. Applying parents' education, rural residence at age 16, region of residence at age 16, number of siblings as instruments for schooling, Sander finds the schooling effects on the probability of quitting smoking estimated by probit and IVprobit estimators to be virtually the same.

More recently, Lleras-Muney (2005) uses compulsory education laws from 1915 to 1939 as instruments for education in the adult mortality equations. When treating schooling as exogenous, she finds the IV estimates on the schooling effect on adult mortality to be negative and significantly larger than the ones obtained by OLS. Adams (2002) demonstrates using the same instruments as Lleras-Muney (2005) that the schooling effect on self-assessed health is much larger in the IV equations than in the OLS equations. Similar results are also obtained by Arendt (2005) when two compulsory schooling reforms in Denmark are used to 
address the endogeneity of schooling in self-assessed health equations. Using changes in compulsory schooling in Sweden which implemented randomly and in stages by municipalities in the 1950s to instrument for schooling, Spasojevic (2003) reports positive schooling effects on a constructed index of bad health and an index of body mass index (BMI) in the healthy range, although the effects are only significant when using one-tailed tests. In short, most studies do not find significant differences in the estimated schooling effects on health whether the schooling variable is treated as exogenous or endogenous.

One important issue concerning the use of IV method to estimate the return to investment in human capital is that the only effect we can be sure that this method estimates is the local average treatment effect (LATE), i.e. the average treatment effect (ATE) among those who alter their status because they react to the instrument (Imbens and Angrist, 1994). In many cases, the instruments used in the return to schooling literature only apply to a small fraction of the population (see, e.g., Angrist and Kruger, 1991). What this implies is that many of the IV estimates will only approximate the ATE among a small and peculiar group rather than the general population, whereas OLS estimates, in the absence of omitted third variables and measurement error problems, approximate ATE among everyone (Card, 2001). For example, as in the aforementioned study by Spasojevic (2003), because school reforms in Sweden took place randomly and in stages by municipalities, it is possible that her IV estimates only approximate the average treatment effects among students who happened to be residing in these municipalities when the changes took place.

Perhaps one of the more successful instruments used to estimate the market returns to education in recent times which, when implemented, will produce the IV estimate that is closest to the ATE for the general population as possible, is the changes in compulsory schooling law in the UK (see Harmon and Walker, 1995; Oreopoulos, 2006). One reason for this is simply because the introduction of the minimum school-leaving age in the UK for the first time in 1947 affects a large fraction of the population who would have left school at age 14 prior to 1947. The dramatic effect of the introduction of such laws on the amount of schooling received by the general population means that the estimated local treatment effects of education will come close to mirroring population average treatment effects (Oreopoulos, 2006).

With respect to the estimation of the compulsory schooling effect on health, Philip Oreopoulos $(2006,2007)$ is among the first to use nation-wide minimum school-leaving age law in the UK to estimate the LATE for schooling on self-assessed health in the nationally representative General Household Survey. Although he finds consistent evidence that 
education improves self-assessed health (a one-year increase in schooling raises the probability of individuals reporting being in good health by $6 \%$ points), there is little evidence that the IV estimates are significantly different from the estimates obtained by OLS. More recently, Silles (2009) finds the effect of compulsory schooling on multiple measures of health (e.g., self-reported health, an indicator of long-term illness, no activity limiting, and no work-preventing) to be positive, statistically significant, and much larger than standard regression estimates suggest.

Although measures of subjective health, mortality outcomes, and health behaviors are reasonably good proxies for health outcomes, they are still far from having the required properties to be representative as a biomarker. By definition, a biomarker is "a characteristic that is objectively measurable and evaluated as an indicator of normal biological processes, pathological processes, or pharmacologic responses to therapeutic intervention.” (Biomarkers Definition Working Groups, 2001, p.91). Certain biomarkers are clinically accepted as the "true” objective measure of an individual's underlying health. For example, reduction of elevated arterial blood pressure has been used for decades by clinicians to reflect the reduction in the stress level and in the incidence of stroke and congestive heart failure, whereas serum cholesterol levels are often used as an indicator of the risk of coronary heart disease (see, for example, Wilson and colleagues, 1998).

Econometric evidence on the relationship between schooling and biomarkers is scarce. Berger and Leigh (1989) use data from the Health and Nutrition Examination Survey to estimate the impact of schooling on reduced blood pressure. Using average real per capita income and expenditures on education in the state in which an individual resided from the year of birth to the age of 6 as their instrumental variables, they found schooling to have a small negative effect on blood pressure: an extra year of schooling reduces both systolic and diastolic blood pressure by approximately -0.6 and $-0.2 \mathrm{mmHg}$, respectively. However, as mentioned previously, their IV estimates obtained by Berger and Leigh are likely to approximate average treatment effects among a subset of population who are responsive to the instruments. Using both the 1998-2007 Health Survey for England and the 2001 Eurobarometer data set, Blanchflower and Oswald (2008, 2009) find schooling to be negatively correlated with blood pressure, although no attempts have been made to treat schooling as exogenous. Like Berg and Leigh, the schooling coefficients obtained in Blanchflower and Oswald, though statistically significant at the $1 \%$ level, are very small and of almost no economic importance. 
Particular mention should be made of recent works - done independently from this study - by Damon Clark and Heather Royer (2008) and Hendrik Jürges, Eberhard Kruk, and Steffen Reinhold (2009). In both articles, the authors estimate the effect of compulsory schooling on different measures of objective health in the Health Survey for England, including biomarker measures such as blood pressure, hypertension, blood fibrinogen and Creactive protein levels. Using only the first raising of the minimum school-leaving age in 1947, Clark and Royer conclude that there is no evidence of compulsory schooling effect reducing the risk of adult hypertension for the whole sample. Jürges, Kruk, and Reinhold also come up with a similar conclusion of no schooling effect when estimated on blood fibrinogen and C-reactive protein levels. The current study extends beyond these two studies by following Devereux and Hart (2010), who conclude that the effect of compulsory schooling on wages in the UK is only positive for males but not for females, and examines the effect of compulsory schooling on adult hypertension by gender. It also adds to the literature by allowing for the unobserved time shocks, which could affect how both schooling and blood pressure variables are collected in the survey, to be controlled for in the regressions in the form of year fixed effects, something which has not been done previously in either study.

\section{Data and empirical strategy}

\section{A. Data}

The data set used in this paper is the Health Survey for England (HSE). The HSE is an annual survey and is designed to monitor the nation's health. The unit of survey in the HSE is the household. Information is collected through a combination of face-to-face interviews, a selfcompleted questionnaire, and a series of medical examination (including taking measurements for height and weight, as well as recording of blood and saliva sample for clinical tests) conducted by a trained nurse. Three continuous blood pressure measurements are available in $99 \%$ of the case, so I take the average for the second and third measures of systolic and diastolic. By definition, systolic blood pressure measures the rate of contraction of heart chambers while driving blood out of the chambers, whereas diastolic blood pressure measures the time when the heart fills with blood after contraction. Both are measured in millimeter of mercury (mmHg). Here, hypertension takes a value of 1 if the person has a systolic blood pressure of $140 \mathrm{mmHg}$ or over and a diastolic blood pressure of $90 \mathrm{mmHg}$ or over, and a value of 0 if the person has a systolic blood pressure below $140 \mathrm{mmHg}$ and a diastolic blood pressure below $90 \mathrm{mmHg}$. This type of categorization forms our main 
dependent variable, although other categorizations of hypertension - i.e. systolic hypertension and diastolic hypertension - will also be analyzed in this study.

The schooling variable is recorded as the age an individual finished full-time education. In this paper, I pool data from the 1991 to 2007 HSEs. Using only the cohorts who were born a few years prior to and post-changes of the compulsory schooling law - $\left(1^{\text {st }}\right.$ change in 1947) those who were born between 1916 and 1951, and ( $2^{\text {nd }}$ change in 1973) those who were born between 1952 and 1975, the first set of cohorts consists of 40,193 observations and 51,287 observations in the second cohort. Summary of descriptive statistics are given in Table A1 in the appendix.

The legislation on changing the minimum school-leaving age from 14 to 15 was first introduced in the 1944 Education Act, with the first increase implemented in 1947. A further increase in the minimum school-leaving age from 15 to 16 subsequently occurred in 1973. Figure 1 plots the fractions of school leavers at age 14 and 15 before and after the first reform in 1947. Figure 2 does the same but for the $2^{\text {nd }}$ reform. Consistent with Harmon and Walker (the UK Family Expenditure Survey) and Oreopoulos (the UK General Household Survey), we can see that a very high fraction of individuals in the HSE left school at age 14 (or less) before 1947. There is, however, a significant drop in the fraction of school leavers at age 14 in 1947: the portion of school leavers at aged 14 fell from 52\% in 1946 to $9 \%$ in 1950 . A sharp - albeit relatively smaller - drop in the portion of 15 years-old school leavers occurred in 1973: Over the course of three years between 1972 and 1975, the fraction of school-leavers at age 15 (or less) fell from $38 \%$ to $15 \%$.

\section{B. RD and IV-probit approach}

This paper focuses on one particular prediction made on the demand for health by Grossman's human capital model: the causal effect of schooling on subsequent health outcomes. Two econometric strategies are adopted here: regression discontinuity (RD) and IV-probit.

First, the RD approach. Following Card and Lee (2006) and more specifically, Clark and Royer (2008), a standard procedure for estimating the causal effect of compulsory schooling on a health outcome is to estimate the following pair of equations:

$$
S_{i c}=\beta_{0}+\beta_{1} D_{i c}+X_{i c}^{\prime}+u_{i c}
$$


$H P_{i c}=\gamma_{0}+\gamma_{1} D_{i c}+X_{i c}^{\prime}+v_{i c}$

Here, $S_{i c}$ is the number of years formal schooling completed for individual $i$ in birth cohort $c$ (calculated from date-of-birth and is defined yearly), $H P_{i c}$ is a binary variable representing whether the individual has a stage I hypertension (systolic blood pressure $>140 \mathrm{mmHg}$ and diastolic blood pressure $>90 \mathrm{mmHg}$ ), $D_{i c}$ is a dummy for whether the individual is affected by the change in the minimum school-leaving age (i.e., for the 1947 reform, $D_{i c}$ will take a value of 1 if the individual was 14 from 1947 onwards, and zero otherwise), $X_{\text {ic }}^{\prime}$ is a vector of control variables, which include smooth functions of birth cohort and age (low-order polynomials) and year dummies. Both birth cohort and age polynomials are included to capture age and cohort trends in the outcome variables of equations (1) and (2). Year fixed effects are added to control for the unobserved time shocks in both outcome variables which can vary from one year to the next in the survey.

Least squares estimation of (1) and (2) will generate $\beta_{1}$ and $\gamma_{1}$, which represent the causal effect of compulsory education on school-leaving age and hypertension respectively. These estimates thus signify the "jump" in both education and health outcome associated with being 14 after the date of the reform, and the ratio of the estimates $\left(\gamma_{1} / \beta_{1}\right)$ will give the standard IV Wald estimate, which is also a LATE estimate (see Damon and Royer, 2008).

Nonetheless, given that our hypertension variable is a binary outcome variable, estimating equation (2) using least squares estimation may yield inconsistent results. For this reason, I also adopt an IV-probit approach to estimate the LATE for schooling on hypertension (Newey, 1987). In IV-probit estimation, the identification is achieved by the inclusion of a dummy variable that records the exogenous change in the minimum schoolleaving age law in the UK in the first-stage regression (see equation (1) above). A probit model on hypertension that incorporates the instrumented schooling as an explanatory variable will then be estimated in the second stage, controlling for birth cohort and age polynomials and year fixed effects. All regressions are clustered by birth cohort, and robust standard errors are reported.

\section{Results}


Following Damon and Royer (2008), Figures 2 and 3 adopt the RD approach and provide the graphic illustrations of the compelling effects of the two reforms on educational attainment (see also Oreopoulos, 2006, and Imbens and Lemieux, 2008). Aggregating the data into cell means by birth year in order to create cohort averages, Figure 2 plots the average age cohorts left full-time education by the year they were age 14 between 1930 and 1965 (i.e. cohorts 1916-1951). Figure 3 does the same but for those who were age 15 between 1965 and 1990 (i.e. cohorts 1952-1975). Note that these fitted values are obtained from regressing the means on birth cohort and age polynomials (cubed), year fixed effects, and a dummy for whether or not a cohort faced a minimum school-leaving age - age 15 for cohorts 1916-1951, and 16 for cohorts 1952-1975. The vertical line in Figure 2 represents the change of minimum schoolleaving age from 14 to 15 in 1947 and, in Figure 3, from 15 to 16 in 1973. Consistent with Oreopoulos (2006), we can see a clear jump in the average age left full-time education after both reforms. The fit predicts an increase in the schooling level between 1946 and 1947 of 0.45 years, and between 1972 and 1973 of approximately 0.16 years.

Figure 4 and 5 plot the corresponding mean hypertension using cohorts 1916-1951 and 1952-1975 respectively. There appears to be a negative - albeit very slight - “jump” in the mean hypertension between 1942 and 1943, as well as between 1972 and 1973 . The ratio of the estimates $\left(\gamma_{1} / \beta_{1}\right)$ is $-0.037(-0.015 / 0.420)$ for cohorts $1916-1951$ (i.e. the $1^{\text {st }}$ reform in 1947), and $-0.012(-0.002 / 0.156)$ for cohorts $1952-1975$ (i.e. the $2^{\text {nd }}$ reform in 1973) respectively. This seems to be consistent with the findings obtained by Damon and Royer (2008) and Jürges, Kruk, Reinhold (2009), which conclude that there is insignificant compulsory schooling effect on adult blood pressure, hypertension, blood fibrinogen and Creactive protein levels.

Given that men and women may benefit differently from the reforms (Devereux and Hart, 2010), I re-estimate equations (1) and (2 by gender and report the corresponding results in Figures 6-8. We can see from these figures that, while the two reforms significantly raise the level of educational attainment for both men and women in both cohorts, the effect of compulsory schooling on hypertension is only negative and statistically significant for men but not for women. Looking at Figure $6 \mathrm{~B}$, we can see that there is a noticeable jump in the mean hypertension between 1946 and 1947 of -0.03-points, which is also statistically significant at the 5\% level. The equivalent jump between 1972 and 1973 (see Figure 7B) is 0.02, with a statistically well-determined standard error of 0.006 . The ratio of the estimates $\left(\gamma_{1} / \beta_{1}\right)$ is $-0.079(-0.015 / 0.420)$ for cohorts $1916-1951$ (i.e. the $1^{\text {st }}$ reform in 1947), and - 
$0.136(-0.019 / 0.138)$ for cohorts $1952-1975$ (i.e. the $2^{\text {nd }}$ reform in 1973) respectively. In other words, the $1^{\text {st }}$ reform leads to a reduction in the risk of men developing hypertension by $8 \%$, whilst the $2^{\text {nd }}$ reform reduces the risk of hypertension by $14 \%$.

By contrast, there appears to be no discontinuity in the mean hypertension for women who were born between 1916 and 1951. Surprisingly, women who were born between 1952 and 1975 experienced a positive jump in the mean hypertension between 1972 and 1973, which implies that the second raising of the minimum school-leaving age had actually increased the risk of hypertension for these women.

The RD approach may nevertheless lead to some imprecision, given that hypertension is a binary outcome variable and not a continuous outcome variable. To allow for the fact that the dependent variable is a [0,1] variable, Table 1 estimates for cohorts 1916-1951 the effect of education on adult hypertension using both probit and IV-probit models. Column 1 shows that, without age controls and year fixed effects, the coefficient on educational attainment (i.e. school leaving age) is roughly -0.019, with a statistically well-defined standard error of 0.006. Adding a cubed age control and year dummies reduces this coefficient to around 0.016 .

In the first-stage regression, the minimum school-leaving age variable enters the schooling equation positively and statistically significantly at the $1 \%$ level. Independent of birth cohort polynomials, age polynomials, and year fixed effects, individuals who faced the minimum school-leaving age of 15 have approximately 0.45 year more full-time education than those who faced the minimum-schooling age of 14 . Note that the 0.45 years jump in the schooling level after 1947 corresponds to the prediction made in Figure 1.

The IV-probit estimates of the schooling effects on hypertension are reported in the last three columns of Table 1 . We can see that there is a negative albeit statistically insignificant relationship between schooling and hypertension; the coefficient on schoolleaving age with a full set of controls is -0.090 and a standard error of 0.074 . The insignificant effect of compulsory schooling on hypertension on the whole sample is therefore consistent with Damon and Royer (2008) and what was obtained earlier in the RD regression in Figure 3.

A significant pattern emerges, however, when the IV-probit model is estimated separately, first on the male subsample and then later on the female subsample. Using the same birth cohorts (i.e. 1916-1951), the IV-probit estimates in Table 2 imply that the introduction of compulsory schooling from 14 to 15 helped reduce the probability of men having hypertension by approximately $7 \%$ compared to the $0.4 \%$ obtained in the probit 
model. By contrast, the corresponding compulsory schooling effect on women's hypertension turns out to be statistically insignificantly different from zero. The impact of education on men's health is even larger in Table 3 (i.e. $-10 \%$ on hypertension) when a narrower window of cohorts, who were born between 1929 and 1939, was used.

Could the results be sensitive to the way hypertension is defined? So far in this paper, a person is said to have hypertension if his or her measured systolic BP $>=140 \mathrm{mmHg}$ and diastolic BP $>=90 \mathrm{mmHg}$, and no hypertension if systolic BP $<140 \mathrm{mmHg}$ and diastolic BP $<90 \mathrm{mmHg}$. However, according to the British Heart Foundation, a person is said to have hypertension if his or her systolic BP is $140 \mathrm{mmHg}$ or over, or his or her diastolic BP is 90 mmHg or over. These ranges are known by clinicians as the ranges representing Stage I hypertension, and individuals with blood pressure within these ranges are normally required medical consultation or a lifestyle change. In addition to this, we can also define hypertension further by assigning a value of 1 to those with systolic BP >= $140 \mathrm{mmHg}$ and diastolic BP >= $90 \mathrm{mmHg}$, and 0 otherwise. This method includes everyone with a valid BP reading.

The estimation of different dependent variables is carried out for both genders in Table 4 where IV-probit models of systolic hypertension, diastolic hypertension, and hypertension ( $2^{\text {nd }}$ definition) equations are estimated. Whilst IV-probit yields the estimated schooling effect that is negative and significant at the $5 \%$ level in the hypertension $\left(2^{\text {nd }}\right.$ definition) equation for men, the effect of compulsory schooling on the less demanding definition of hypertension (i.e. systolic BP $>=140 \mathrm{mmHg}$ or diastolic BP $>=90 \mathrm{mmHg}$ ) is negative but nevertheless statistically indifferent from zero in all other columns. What this implies is that the effect of compulsory education at reducing hypertension is perhaps more well-defined for those with high systolic and diastolic blood pressures.

Table 5 moves on to examine by gender the effect of the $2^{\text {nd }}$ reform in 1973 on adult hypertension. Using the second group of cohorts (i.e. those who were born between 1952 and 1975), the estimated IV schooling coefficient in the male subsample continues to be negative, statistically significant, and markedly larger than the one estimated by its probit counterpart. Controlling for birth cohort polynomials, age polynomials, and year fixed effects, the change in the minimum school-leaving age from 15 to 16 lowers the probability of developing hypertension by approximately $12 \%$ for men. By contrast, the marginal effect of compulsory education is positive and statistically well-determined at the $1 \%$ level for women: For women in these cohorts, having one more year of schooling raises the probability of developing hypertension in adulthood by approximately $7 \%$. 


\section{Conclusion}

This paper contributes to the literature of human capital by estimating the biomarker effect of compulsory schooling. Using two education reforms in the UK as instruments in a variety of blood pressure equations, the RD and IV-probit estimates imply that completing an additional year of schooling helps reduce the probability of men developing subsequent hypertension by approximately 7\%-12\% points. Similar to the conclusion made by Devereux and Hart (2010), women do not seem to have benefitted at all from the raising of the minimum school-leaving age. In the IV-probit regressions, the correct estimates of the LATE for schooling for men indicate the presence of a large and negative bias in the probit estimates of schooling-health relationship. Furthermore, given the compelling effects of the changes in the minimum school-leaving age laws in the UK in both 1947 and 1973, it is likely that my IV estimates of the schooling effect on hypertension are close to mirroring the ATE for the general male population in England (Oreopoulos, 2006).

This paper has important policy implications. First, it provides partial evidence in favor of Grossman (1975) who has suggested that an increase in expenditure on education rather than on health itself is perhaps the most cost effective way to improve the nation's health. Secondly, according to the Office for National Statistics in the UK, death by heart disease explains around $20 \%$ of total death in 2005 , which is considerably higher than the second-place killer: cerebrovascular diseases (8\%), and the third-place killer: lung cancer (7\%). If an additional year of schooling can help reduce the incidence of hypertension among men by up to 12-percentage-points, then the implications of a nationwide change in the minimum school-leaving age from 16 to 18, which is scheduled to take place in 2013, on the nation's well-being may have been underestimated if one was to simply look at the market returns to education. Finally, the different results by gender (beneficial for men but not for women) is of some interest in itself. Further studies should be conducted to uncover the underlying mechanisms that education plays in improving men's health but not for women's.

The results of this paper also call for further inquiry into the estimation of compulsory schooling on other biomarkers, including, among others, cholesterol and cortisol levels, in order for academics and policy makers to obtain a more complete picture of the relationship between schooling and the true health of a nation. 


\section{Reference}

Adams, Scott J. 2002. Educational attainment and health: Evidence from a sample of older adults. Education Economics, 10, 97-109.

Angrist, Joshua D. 2004. Treatment effect heterogeneity in theory and practice, Economic Journal, 114(494), C52-C83.

Angrist, Joshua D., and Kruger, Alan B. 2001. Instrumental variables and the search for identification: From supply to demand and natural experiments. Journal of Economic Perspectives, 15(4), 69-85.

Angrist, Joshua D., and Kruger, Alan B. 1991. Does compulsory school attendance affect schooling and earnings? Quarterly Journal of Economics, 106(4), 979-1014.

Arendt, Jacob N. 2005. Does education cause better health? A panel data analysis using school reforms for identification. Economics of Education Review, 24(2), 149-160.

Behrman, Jere R., and Rosenzweig, Mark R.. 2002. Does increasing women’s schooling raise the schooling for the next generation? American Economic Review, 92, 323-334.

Berger, Mark C., and Leigh, J. Paul. 1989. Schooling, self-selection, and health. Journal of Human Resources, 24(3), 433-455.

Biomarkers Definition Working Groups. 2001. Biomarkers and surrogate endpoints: Preferred definitions and conceptual framework. Clinical, Pharmacology, \& Therapeutics, 69(3), 89-95.

Blackburn, McKinley L., and Neumark, David. 1995. Are OLS estimates of the return to schooling biased downward? Another look. Review of Economics and Statistics, 77(2), 217229.

Blanchflower, David G., and Oswald, A.J. 2008. Hypertension and happiness across nations. Journal of Health Economics, 27(2), 218-233.

Blanchflower, David G., and Oswald, A.J. 2009. Hypertension and happiness across regions. Department of Economics, University of Warwick, mimeo.

Card, David. 1995. Using geographic variation in college proximity to estimate the return to schooling. In Louis N. Christofides, E. Kenneth Grant, and Robert Swindisky (eds.), Aspects of Labour Market Behaviour: Essays in Honor of John Vanderkamp. Toronto: University of Toronto Press, p.201-222.

Card, David. 2001. Estimating the return to schooling: Progress on some persistent econometric problems. Econometrica, 69, 1127-1160. 
Card, David, and Lee, David S. 2008. Regression discontinuity inference with specification error. Journal of Econometrics, 142, 655-674.

Case, Anne; Fertig, Angela, and Paxson, Christina. 2005. The lasting impact of childhood health and circumstance. Journal of Health Economics, 24, 365-389.

Chou, Shin-Yi; Grossman, Michael, and Saffer, Henry. 2004. An economic analysis of adult obesity: Results from the behavioral risk factor surveillance system. Journal of Health Economics, 23(3), 565-587.

Clark, Damon, and Royer, Heather. 2008. The effect of education on adult mortality and health: evidence from the United Kingdom. Department of Economics: Dartmouth University, manuscript.

Devereux, Paul J., and Hart, Robert A. 2010. Forced to be rich? Returns to compulsory schooling in Britain. Economic Journal, forthcoming.

De Walque, Damien. 2007. How does the impact of an HIV/AIDS information campaign vary with education attainment? Journal of Development Economics, 84(2), 686-714.

Erbsland, Manfred; Reid, Walter, and Ulrich, Volker. 1995. Health, health care, and the environment. Econometric evidence from the German micro data. Health Economics, 4(3), 169-182.

Fraser, Gary E. 1986. Preventive Cardiology. New York: Oxford University Press.

Fuch, Victor R. 1982. Time preference and health: An exploratory study. In Victor R. Fuch (ed), Economic Aspects of Health, University of Chicago Press: Chicago, p.93-120.

Gerdtham, Ulf-G., and Johannesson, Magnus. 1999. New estimates of the demand for health: Results based on a categorical health measure and Swedish micro data. Social Science \& Medicine, 49, 1325-1332.

Goldman, Dana, and Smith, James P. 2002. Can patient self-management help explain the SES health gradient? Proceedings of the National Academy of Sciences of the United States, 99, 10929-10934.

Grossman, Michael. 1972. The demand for health: A theoretical and empirical investigation. Columbia University Press for the National Bureau of Economic Research: New York. Grossman, Michael. 1975. The correlation between health and schooling. In Nestor E. Terleckyj (ed.), Household Production and Consumption, Columbia University Press for the National Bureau of Economic Research: New York, p.147-211.

Grossman, Michael. 2000. The human capital model. In Antony J. Culyer and Joseph P. Newhouse (eds.), Handbook of Health Economics, Vol. 1A, Elsevier: Amsterdam, p.347-408. 
Grossman, Michael. 2005. Education and nonmarket outcomes. NBER Working Paper 11582.

Harmon, Colm, and Walker, Ian. 1995. Estimates of the return to schooling for the United Kingdom. American Economic Review, 85(5), 1278-1286.

Hartog, Joop, and Oosterbeek, Hessel. 1998. Health, wealth, and happiness: Why pursue a higher education? Economics of Education Review, 17, 245-256.

Hoffman, Albert; Feinleib, Manning; Garrison, Robert J., and van Laar, Abraham. 1983. Does change in blood pressure predict heart disease? British Medical Journal, 287, 267-269.

Imbens, Guido W., and Angrist, Joshua D. 1994. Identification and estimation of local average treatment effects. Econometrica, 62(2), 467-475.

Imbens, Guido W., and Lemieux, Thomas. 2008. Regression discontinuity designs: A guide to practice. Journal of Econometrics, 142(2), 615-635.

Jürges, Hendrik ; Kruk, Eberhard, and Reinhold, Steffen. 2009. The effect of compulsory schooling on health: evidence from biomarkers. MEA Discussion Paper 183-09.

Kenkel, Donald S. 1991. Health behavior, health knowledge, and schooling. Journal of Political Economy, 99(2), 287-305.

Leigh, J. Paul, and Dhir, Rachna. 1997. Schooling and frailty among seniors. Economics of Education Review, 16(1), 45-57.

Lleras-Muney, Adriana. 2005. The relationship between education and adult mortality in the United States. Review of Economics Studies, 72, 189-221.

Newey, Whitney K. 1987. Efficient estimation of limited dependent variable models with endogenous explanatory variables. Journal of Econometrics, 36(3), 231-250.

Oreopoulos, Philip. 2006. Estimating local and average treatment effects when compulsory schooling really matter. American Economic Review, 96(1), 152-175.

Oreopoulos, Philip. 2007. Do dropouts drop out too soon? Wealth, health and happiness from compulsory schooling. Journal of Public Economics, 91(11-12), 2213-2229.

Powdthavee, Nattavudh. 2009. Ill-health as a household norm: Evidence from other people's health problems. Social Science \& Medicine, 68, 251-259.

Sander, William. 1995. Smoking and quitting smoking. Review of Economics and Statistics, 77, 191-199.

Silles, Mary A. 2009. The causal effect of education on health: evidence from the United Kingdom. Economics of Education Review, 28, 122-128. 
Spasojevic, Jelena. 2003. Effects of education on adult health in Sweden: Results from a natural experiment. PhD Dissertation, City University of New York Graduate Center, New York.

Wagstaff, Adam. 1986. The demand for health: Some new empirical evidence. Journal of Health Economics, 5(3), 195-233.

Wilson, Peter W.F., and colleagues. 1998. Prediction of coronary heart disease using risk factor categories. Circulation, 97, 1837-1847. 
Figures 1A \& 1B: Fraction of Students Left Full-Time Education By Age 14 and 15,

$\underline{\text { HSE 1991-2007 }}$

Fig.1A

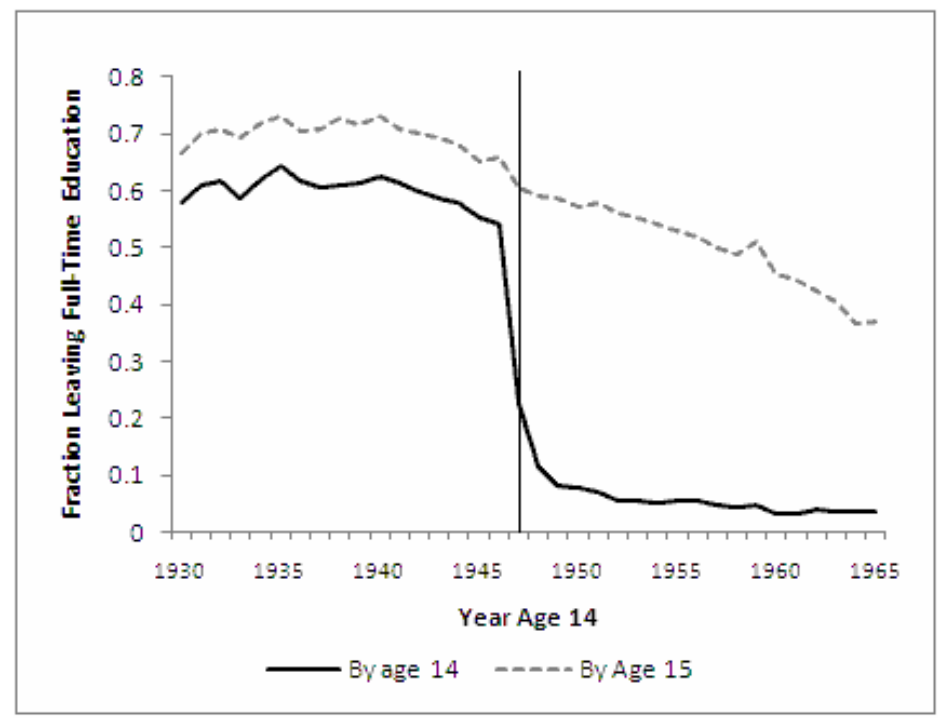

Fig.1B

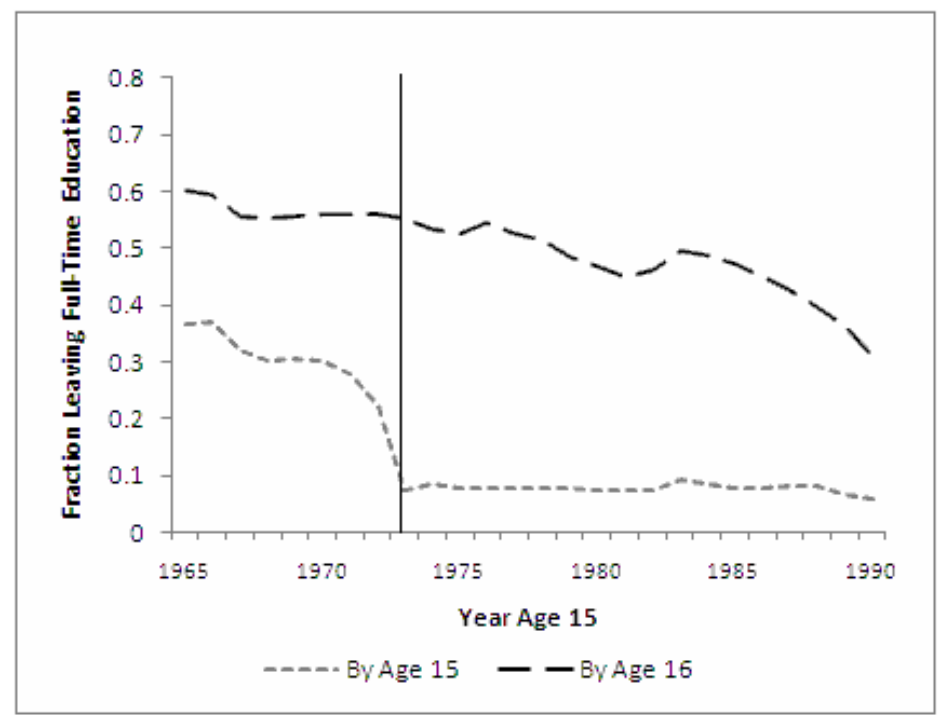

Note: the bottom line in Fig.1A represents the proportion of adults in the HSE who left school at or before the age of 14 between 1930 and 1965, and the top is the same but for age 15. The bottom line in Fig.1B represents the proportion of adults in the HSE who left school at or before the age of 15 between 1965 and 1990, and the top is the same but for age 16.Note that the first introduction of minimum school-leaving age law in the United Kingdom took place in 1947 (from age 14 to 15) and then again in 1973 (from age 15 to 16), as indicated by the vertical lines. 
Figure 2: Local Averages and Parametric Fit of Average Schooling Age

By Year Aged 14 (Age-Adjusted and Time-Detrended)

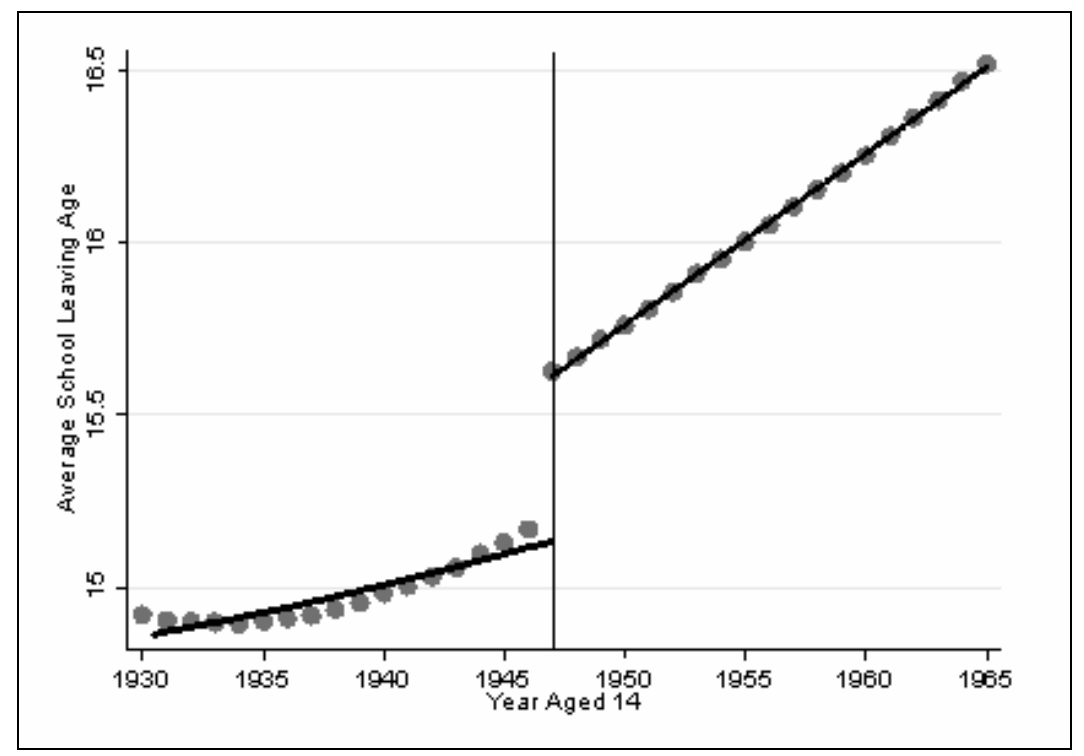

Note: Local averages are plotted for English individuals who were aged 14 between 1930 and 1965 . The line represents the predicted fit by regressing mean age finished full-time education on a birth cohort cubed polynomial, age cubed polynomial, surveyed year fixed effects, and an indicator for the school leaving age faced at 14 . The circles represent local averages. The minimum school-leaving age was raised from age 14 to 15 in 1947, as indicated by the vertical line. 
Figure 3: Local Averages and Parametric Fit of Average Schooling Age

By Year Aged 15 (Age-Adjusted and Time-Detrended)

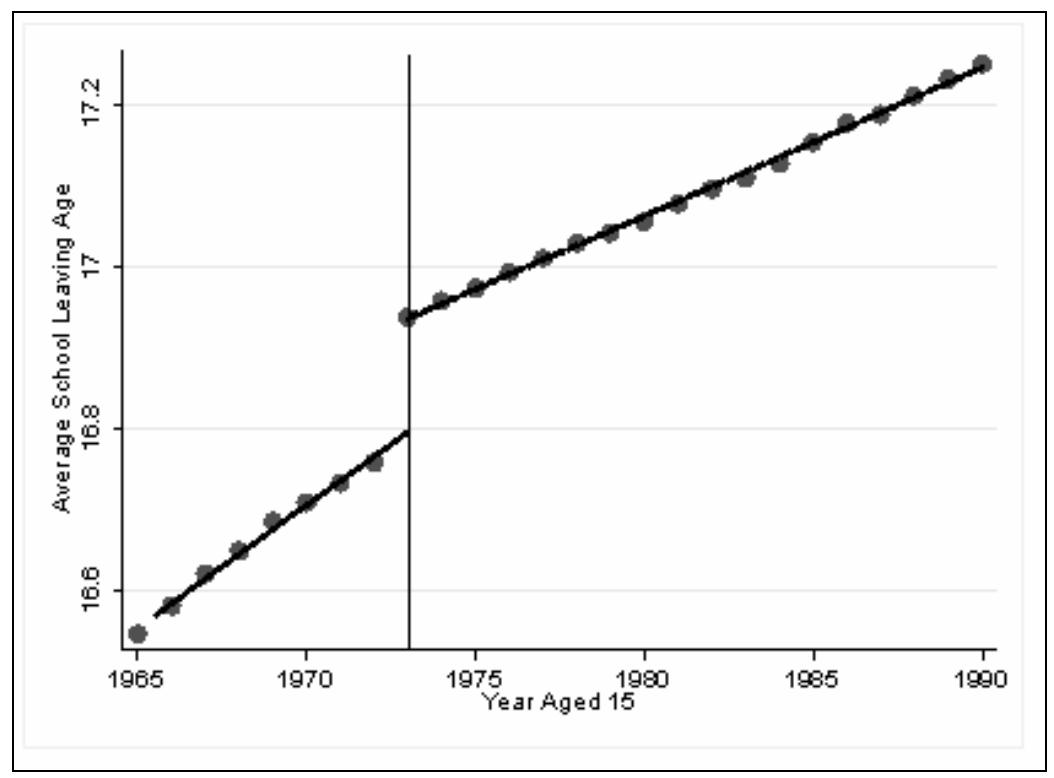

Note: Local averages are plotted for English individuals who were aged 15 between 1965 and 1990. The line represents the predicted fit by regressing mean age finished full-time education on a birth cohort cubed polynomial, age cubed polynomial, surveyed year fixed effects, and an indicator for the school leaving age faced at 15 . The circles represent local averages. The minimum school-leaving age was raised from age 15 to 16 in 1973 , as indicated by the vertical line. 


\section{Figure 4: Local Averages and Parametric Fit of Average Hypertension}

By Year Aged 14 (Age-Adjusted and Time-Detrended)

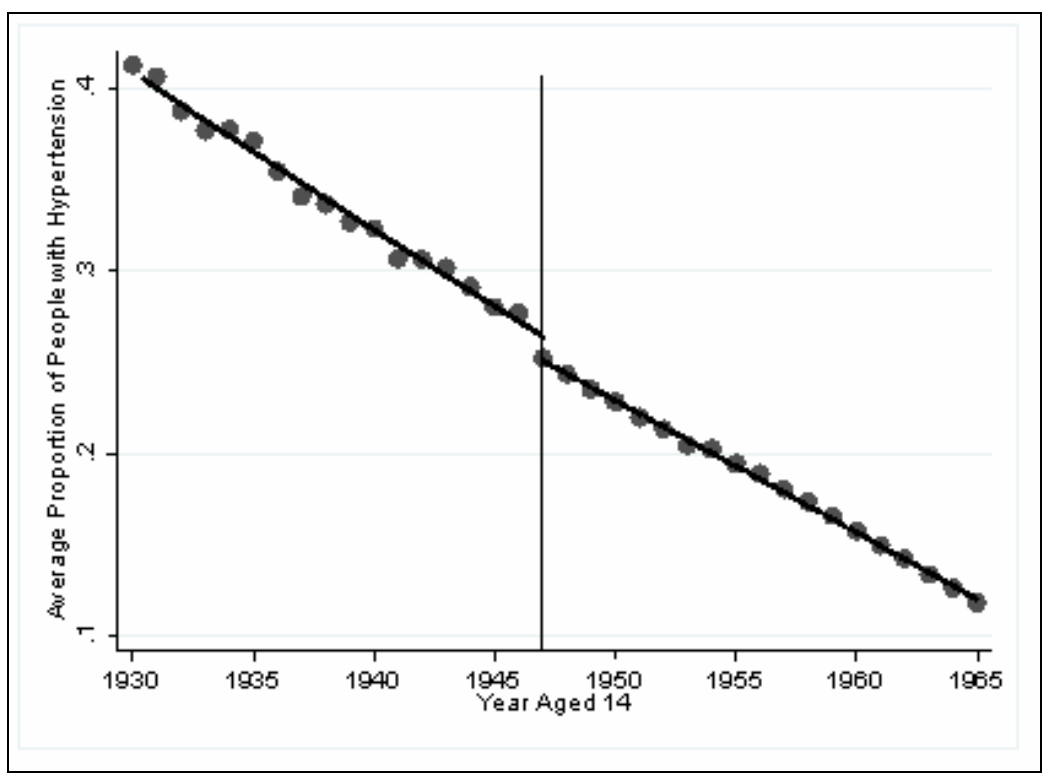

Note: Local averages are plotted for English individuals who were aged 14 between 1930 and 1965 . The line represents the predicted fit by regressing mean hypertension (systolic $\mathrm{BP}>=140$ and diastolic $\mathrm{BP}>=90$ ) on a birth cohort cubed polynomial, age cubed polynomial, surveyed year fixed effects, and an indicator for the school leaving age faced at 14 . The circles represent local averages. The minimum school-leaving age was raised from age 14 to 15 in 1947 , as indicated by the vertical line. 


\section{Figure 5: Local Averages and Parametric Fit of Average Hypertension}

\section{By Year Aged 15 (Age-Adjusted and Time-Detrended)}

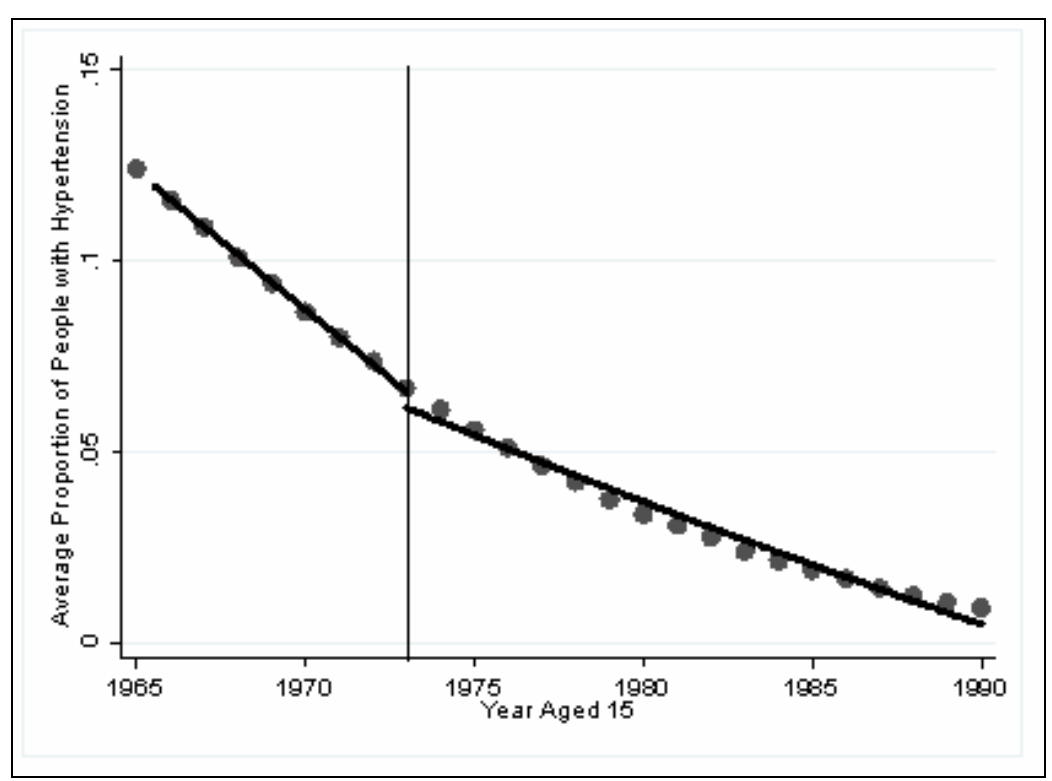

Note: Local averages are plotted for English individuals who were aged 15 between 1965 and 1990. The line represents the predicted fit by regressing mean hypertension (systolic BP $>=140$ and diastolic $\mathrm{BP}>=90$ ) on a birth cohort cubed polynomial, age cubed polynomial, surveyed year fixed effects, and an indicator for the school leaving age faced at 15 . The circles represent local averages. The minimum school-leaving age was raised from age 15 to 16 in 1973, as indicated by the vertical line. 


\section{Figures 6A \& 6B: Local Averages and Parametric Fit of Average Schooling Age and Average Hypertension}

\section{By Year Aged 14 (Male Subsample, Age-Adjusted and Time-Detrended)}

Fig.6A

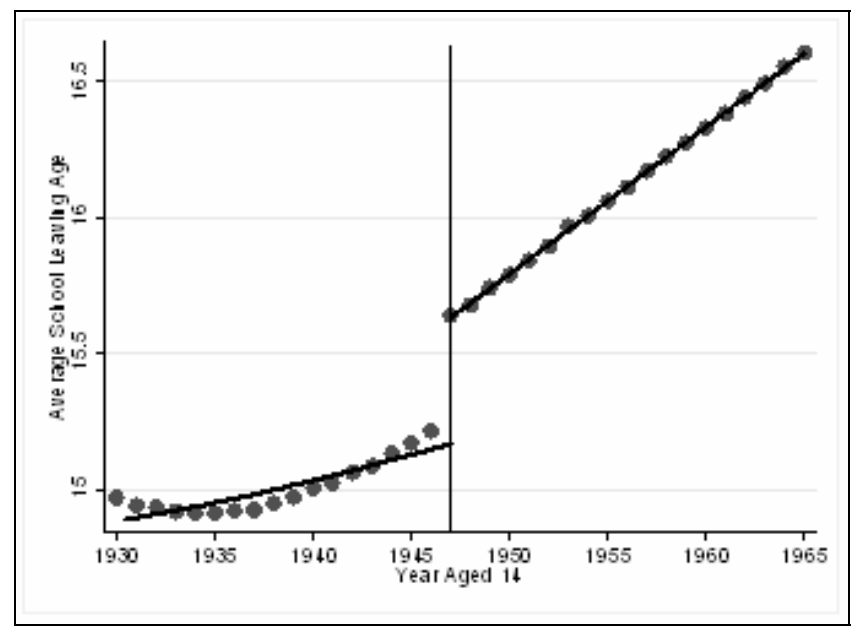

Fig.6B

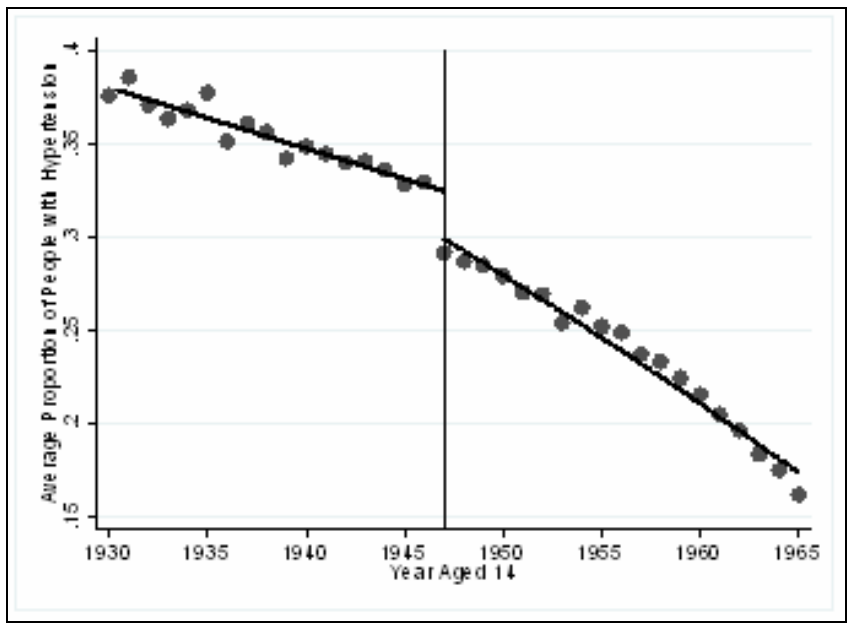

Note: Local averages are plotted for English men who were aged 14 between 1930 and 1965. The line represents the predicted fit by regressing mean age finished full-time education in the first diagram (and average hypertension in the second diagram) on a birth cohort cubed polynomial, age cubed polynomial, surveyed year fixed effects, and an indicator for the school leaving age faced at 14 . The circles represent local averages. The minimum school-leaving age was raised from age 14 to 15 in 1947 , as indicated by the vertical line. 
Figures 7A \& 7B: Local Averages and Parametric Fit of Average Schooling Age and Average Hypertension

By Year Aged 15 (Male Subsample, Age-Adjusted and Time-Detrended)

Fig.7A

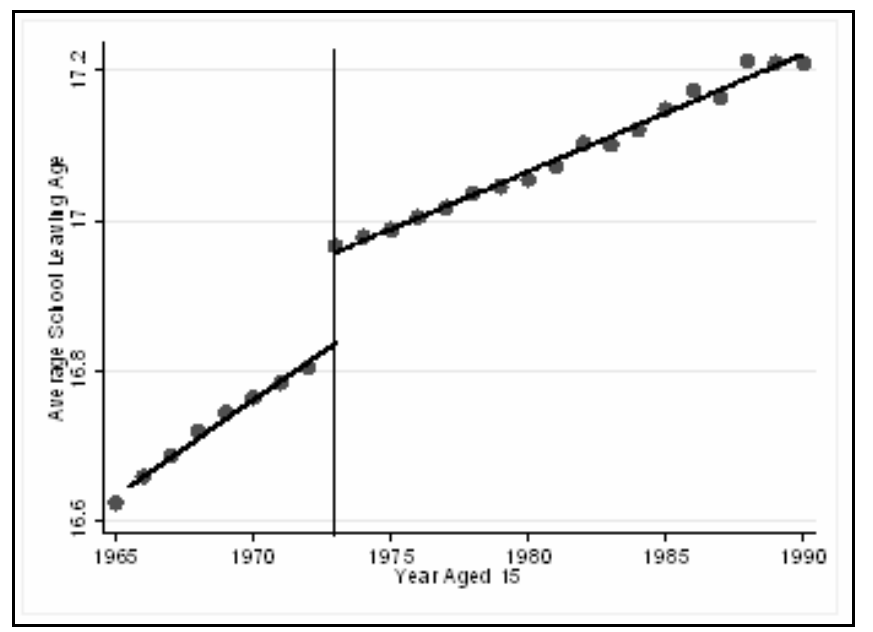

Fig.7B

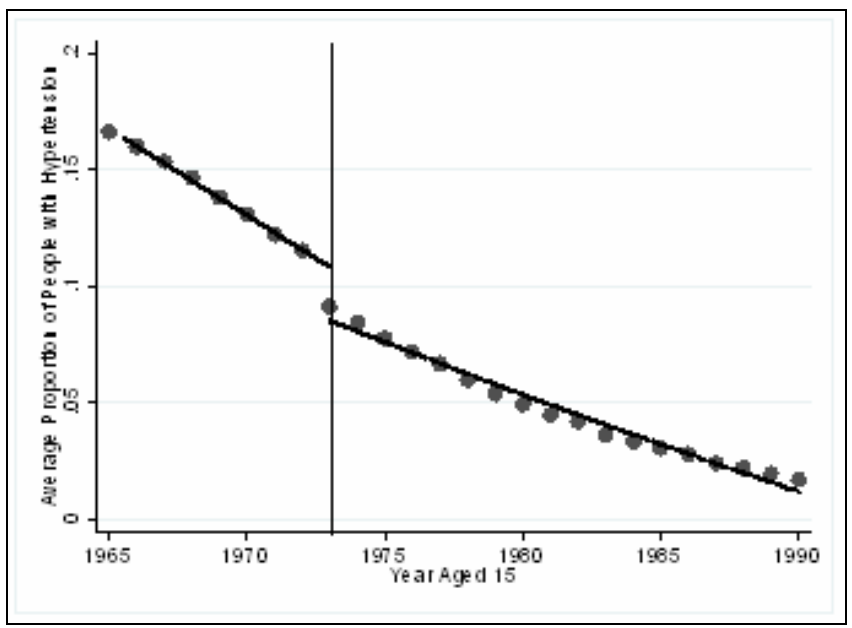

Note: Local averages are plotted for English men who were aged 15 between 1965 and 1990. The line represents the predicted fit by regressing mean age finished full-time education in the first diagram (and average hypertension in the second diagram) on a birth cohort cubed polynomial, age cubed polynomial, surveyed year fixed effects, and an indicator for the school leaving age faced at 15 . The circles represent local averages. The minimum school-leaving age was raised from age 15 to 16 in 1973 , as indicated by the vertical line. 


\section{Figures 8A \& 8B: Local Averages and Parametric Fit of Average Schooling Age and Average Hypertension}

\section{By Year Aged 14 (Female Subsample, Age-Adjusted and Time-Detrended)}

Fig.8A

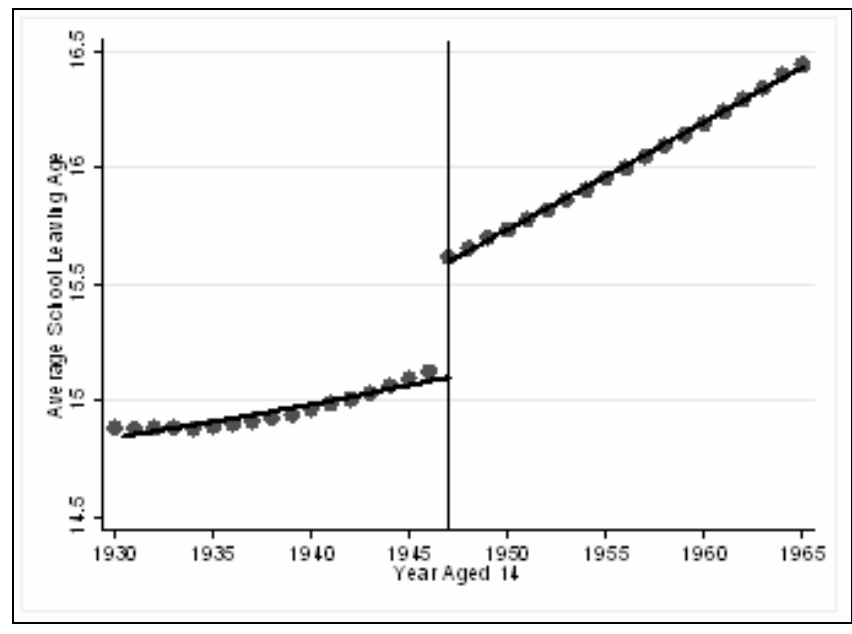

Fig.8B

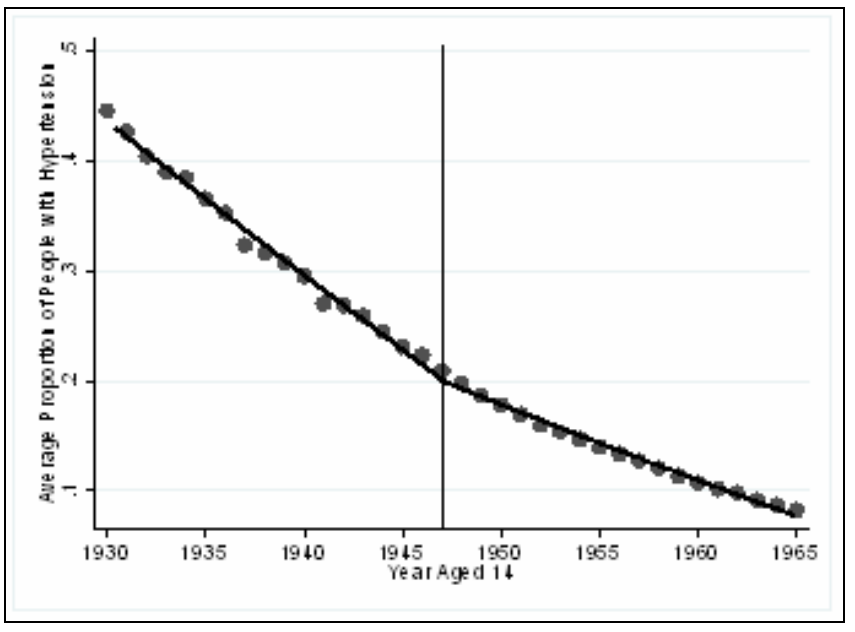

Note: Local averages are plotted for English women who were aged 14 between 1930 and 1965. The line represents the predicted fit by regressing mean age finished fulltime education in the first diagram (and average hypertension in the second diagram) on a birth cohort cubed polynomial, age cubed polynomial, surveyed year fixed effects, and an indicator for the school leaving age faced at 14. The circles represent local averages. The minimum school-leaving age was raised from age 14 to 15 in 1947 , as indicated by the vertical line. 
Figures 9A \& 9B: Local Averages and Parametric Fit of Average Schooling Age and Average Hypertension

By Year Aged 15 (Female Subsample, Age-Adjusted and Time-Detrended)

Fig.9A

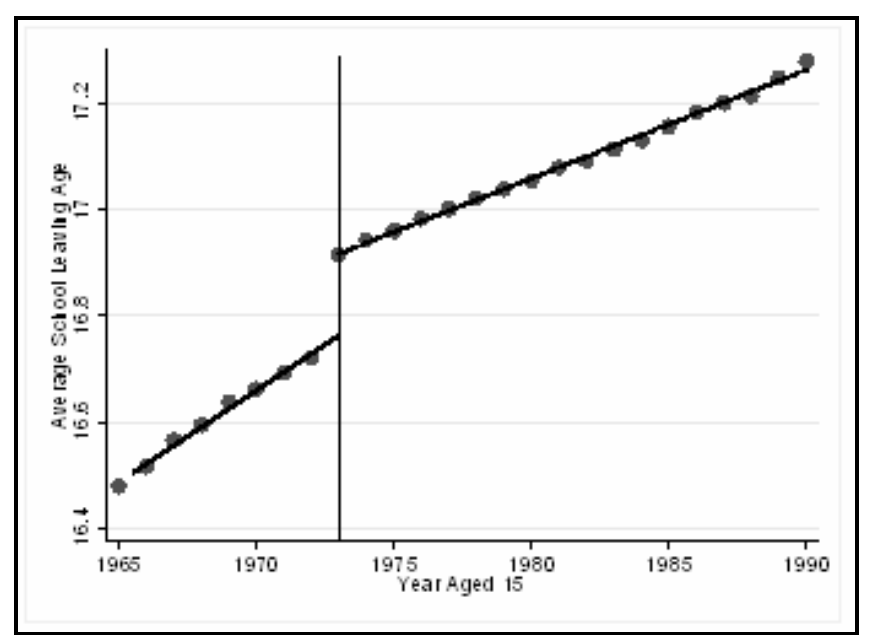

Fig.9B

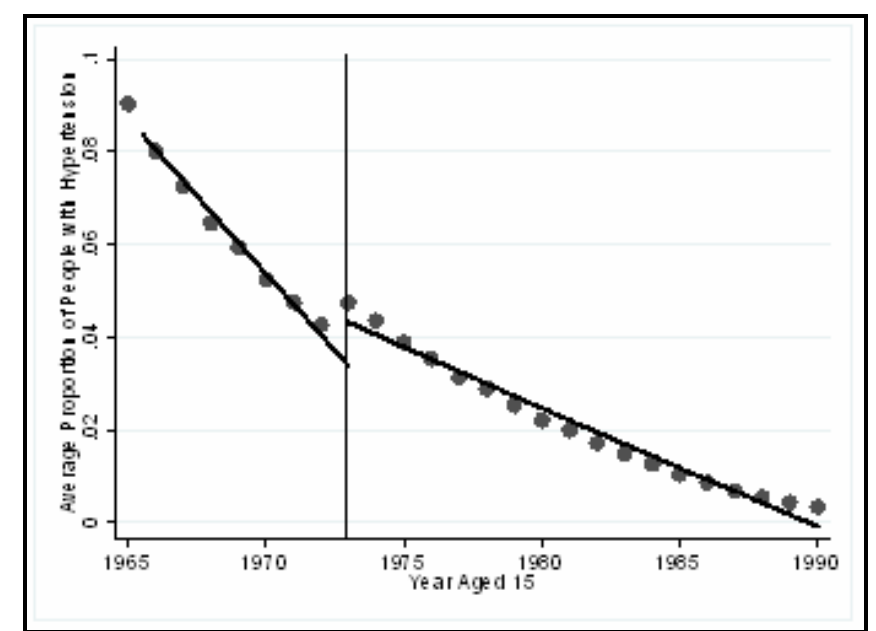

Note: Local averages are plotted for English men who were aged 15 between 1965 and 1990. The line represents the predicted fit by regressing mean age finished full-time education in the first diagram (and average hypertension in the second diagram) on a birth cohort cubed polynomial, age cubed polynomial, surveyed year fixed effects, and an indicator for the school leaving age faced at 15. The circles represent local averages. The minimum school-leaving age was raised from age 15 to 16 in 1973 , as indicated by the vertical line. 


\section{Table 1: Probit, First Stage School Leaving Age Regression, and IV-probit Hypertension Equations,}

\section{Health Survey for England 1991-2007, Cohorts 1916-1951}

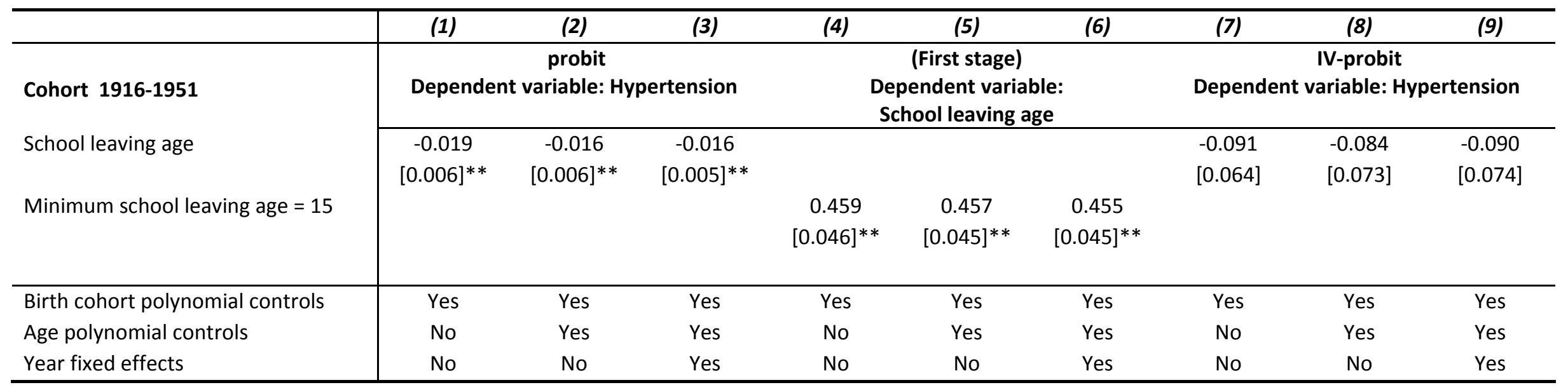

Note: $* *<1 \% . \mathrm{N}=40,193$ in all columns. Dependent variable: Hypertension $(\mathrm{BP}>=140$ and $\mathrm{BP}>=90=1$, and $\mathrm{BP}<140$ and $\mathrm{BP}<90=0)$. Robust standard errors are in parentheses, and are clustered by birth cohort. The raising of the minimum school leaving age from 14 to 15 took place in 1947. 
Table 2: Probit, First Stage School Leaving Age Regression, and IV-probit Hypertension Equations by Gender,

\section{Health Survey for England 1991-2007, Cohorts 1916-1951}

\begin{tabular}{|c|c|c|c|c|}
\hline $\begin{array}{l}\text { 1) Men } \\
\text { Cohort 1916-1951 }\end{array}$ & $\begin{array}{c}\text { (1) } \\
\text { probit }\end{array}$ & (First Stage) & IV-probit & $\begin{array}{c}\text { (4) } \\
\text { Percentage of } \\
\text { people with } \\
\text { hypertension }\end{array}$ \\
\hline School leaving age & $\begin{array}{c}-0.013 \\
{[0.008]+}\end{array}$ & & $\begin{array}{c}-0.215 \\
{[0.076]^{* *}}\end{array}$ & \\
\hline Minimum school leaving age $=15$ & & $\begin{array}{c}0.389 \\
{[0.052]^{* *}}\end{array}$ & & \\
\hline Marginal effect of one extra year of full-time education & $-0.42 \%$ & & $-7.04 \%$ & $26.74 \%$ \\
\hline $\begin{array}{l}\text { 2) Women } \\
\text { Cohort 1916-1951 }\end{array}$ & $\begin{array}{c}\text { (5) } \\
\text { probit }\end{array}$ & (6) & IV-probit & $\begin{array}{c}\text { (8) } \\
\text { Percentage of } \\
\text { people with } \\
\text { hypertension }\end{array}$ \\
\hline School leaving age & $\begin{array}{c}-0.029 \\
{[0.007]^{* *}}\end{array}$ & & $\begin{array}{c}0.013 \\
{[0.128]}\end{array}$ & \\
\hline Minimum school leaving age $=15$ & & $\begin{array}{c}0.520 \\
{[0.064]^{* *}}\end{array}$ & & \\
\hline Marginal effect of one extra year of full-time education & $-0.71 \%$ & & $0.33 \%$ & $17.79 \%$ \\
\hline
\end{tabular}

Note: $+<10 \%, * *<1 \% . \mathrm{N}=19,158$ (male subsample) and 21,035 (female subsample). Robust standard errors are in parentheses, and are clustered by birth cohort. Same control variables (i.e. birth cohort cubed polynomial, age cubed polynomial, and year fixed effects) as in Table 1. 
Table 3: Probit, First Stage School Leaving Age Regression, and IV-probit Hypertension Equations by Gender,

\section{Health Survey for England 1991-2007, Cohort 1929-1939}

\begin{tabular}{|c|c|c|c|c|}
\hline $\begin{array}{l}\text { 1) Men } \\
\text { Cohort 1929-1939 }\end{array}$ & $\begin{array}{c}\text { (1) } \\
\text { probit }\end{array}$ & (First Stage) & IV-probit & $\begin{array}{c}\text { (4) } \\
\text { Percentage of } \\
\text { people with } \\
\text { hypertension }\end{array}$ \\
\hline School leaving age & $\begin{array}{l}-0.005 \\
{[0.018]}\end{array}$ & & $\begin{array}{c}-0.293 \\
{[0.070]^{* *}}\end{array}$ & \\
\hline Minimum school leaving age $=15$ & & $\begin{array}{c}0.388 \\
{[0.063]^{* *}}\end{array}$ & & \\
\hline Marginal effect of one extra year of full-time education & $-0.17 \%$ & & $-10.12 \%$ & $27.69 \%$ \\
\hline $\begin{array}{l}\text { 2) Women } \\
\text { Cohort 1929-1939 }\end{array}$ & $\begin{array}{c}\text { (5) } \\
\text { probit }\end{array}$ & (6) & IV-probit & $\begin{array}{c}\text { (8) } \\
\text { Percentage of } \\
\text { people with } \\
\text { hypertension }\end{array}$ \\
\hline School leaving age & $\begin{array}{l}-0.012 \\
{[0.013]}\end{array}$ & & $\begin{array}{c}0.105 \\
{[0.263]}\end{array}$ & \\
\hline Minimum school leaving age $=15$ & & $\begin{array}{c}0.520 \\
{[0.064]^{* *}}\end{array}$ & & \\
\hline Marginal effect of one extra year of full-time education & $-0.33 \%$ & & $2.88 \%$ & $19.26 \%$ \\
\hline
\end{tabular}

Note: $* *<1 \% . \mathrm{N}=6,130$ (male subsample) and 6,039 (female subsample). Robust standard errors are in parentheses, and are clustered by birth cohort. Same control variables (i.e. birth cohort cubed polynomial, age cubed polynomial, and year fixed effects) as in Table 1. 
Table 4: IV-probit Hypertension Equations with Different Dependent Variables,

\section{$\underline{\text { Health Survey for England 1991-2007, Cohorts 1916-1951 }}$}

\begin{tabular}{|c|c|c|c|}
\hline \multirow[b]{4}{*}{ Cohort 1916-1951 } & (1) & (2) & (3) \\
\hline & \multicolumn{3}{|c|}{ IV-probit } \\
\hline & & & \\
\hline & Systolic hypertension & $\begin{array}{c}\text { Diastolic } \\
\text { hypertension }\end{array}$ & $\begin{array}{c}\text { Hypertension (second } \\
\text { definition) }\end{array}$ \\
\hline \multirow[t]{2}{*}{ School leaving age } & -0.022 & -0.141 & -0.187 \\
\hline & {$[0.071]$} & {$[0.100]$} & {$[0.089]^{*}$} \\
\hline $\begin{array}{l}\text { Marginal effect of one extra year } \\
\text { of full-time education }\end{array}$ & $-0.89 \%$ & $-3.69 \%$ & $-4.89 \%$ \\
\hline $\begin{array}{l}\text { Fraction of people with specified } \\
\text { hypertension }\end{array}$ & $48.25 \%$ & $17.86 \%$ & $17.92 \%$ \\
\hline \multirow[t]{2}{*}{$N$} & 28,739 & 28,739 & 28,739 \\
\hline & (4) & (5) & (6) \\
\hline \multicolumn{4}{|l|}{ 2) Women } \\
\hline Cohort 1916-1951 & Systolic hypertension & $\begin{array}{c}\text { Diastolic } \\
\text { hypertension }\end{array}$ & $\begin{array}{l}\text { Hypertensions } \\
\text { (second definition) }\end{array}$ \\
\hline \multirow[t]{2}{*}{ School leaving age } & 0.021 & 0.061 & 0.048 \\
\hline & [0.059] & [0.125] & [0.124] \\
\hline $\begin{array}{l}\text { Marginal effect of one extra year } \\
\text { of full-time education }\end{array}$ & $0.83 \%$ & $1.12 \%$ & $0.89 \%$ \\
\hline $\begin{array}{l}\text { Fraction of people with specified } \\
\text { hypertension }\end{array}$ & $46.03 \%$ & $10.67 \%$ & $10.77 \%$ \\
\hline$N$ & 33,315 & 33,315 & 33,315 \\
\hline
\end{tabular}

Note: $*<5 \%$. Systolic hypertension $=1$ if systolic BP $>140 \mathrm{mmHg}$, and 0 otherwise. Diastolic hypertension = 1 if diastolic BP $>90 \mathrm{mmHg}$, and 0 otherwise. Hypertension (second definition) $=1$ if systolic $\mathrm{BP}>140$ and diastolic $\mathrm{BP}>90$, and 0 otherwise; the zero category also includes those with systolic hypertension and diastolic hypertension. Robust standard errors are in parentheses, and are clustered by birth cohort. Same control variables (i.e. birth cohort cubed polynomial, age cubed polynomial, and year fixed effects) as in Table 1. 
Table 5: Probit, First Stage School Leaving Age Regression, and IV-probit Hypertension Equations by Gender,

\section{Health Survey for England 1991-2007, Cohorts 1952-1975}

\begin{tabular}{|c|c|c|c|c|}
\hline $\begin{array}{l}\text { 1) Men } \\
\text { Cohort 1952-1975 }\end{array}$ & probit & (First Stage) & IV-probit & $\begin{array}{c}\text { (4) } \\
\text { Percentage of } \\
\text { people with } \\
\text { hypertension }\end{array}$ \\
\hline \multirow[t]{2}{*}{ School leaving age } & -0.022 & & -0.499 & \\
\hline & {$[0.008]^{* *}$} & & {$[0.115]^{* *}$} & \\
\hline \multirow[t]{2}{*}{ Minimum school leaving age $=16$} & & 0.101 & & \\
\hline & & {$[0.027]^{* *}$} & & \\
\hline \multirow[t]{2}{*}{ Marginal effect of one extra year of full-time education } & $-0.28 \%$ & & $-11.54 \%$ & $7.90 \%$ \\
\hline & (5) & (6) & (7) & (8) \\
\hline 2) Women & & & & $\begin{array}{l}\text { Percentage of } \\
\text { people with }\end{array}$ \\
\hline Cohort 1952-1975 & probit & (First Stage) & IV-probit & hypertension \\
\hline \multirow[t]{2}{*}{ School leaving age } & -0.027 & & 0.461 & \\
\hline & {$[0.011]^{*}$} & & {$[0.181]^{* *}$} & \\
\hline \multirow[t]{2}{*}{ Minimum school leaving age $=16$} & & 0.153 & & \\
\hline & & {$[0.030]^{* *}$} & & \\
\hline Marginal effect of one extra year of full-time education & $-0.16 \%$ & & $6.77 \%$ & $3.40 \%$ \\
\hline
\end{tabular}

Note: $*<5 \% ; * *<1 \% . N=21,821$ (male subsample) and 29,466 (female subsample). Robust standard errors are in parentheses, and are clustered by birth cohort. The raising of the minimum school leaving age from 15 to 16 took place in 1973. Same control variables (i.e. birth cohort cubed polynomial, age cubed polynomial, and year fixed effects) as in Table 1. 
Table 1A: Summary Statistics (Cohorts 1916-1975)

\begin{tabular}{|c|c|c|c|c|c|c|c|c|}
\hline & \multicolumn{2}{|c|}{ All } & \multicolumn{2}{|c|}{ Left school age 14} & \multicolumn{2}{|c|}{ Left school age 15} & \multicolumn{2}{|c|}{ Left school age 16} \\
\hline & $\mathrm{M}$ & SD & $\mathrm{M}$ & SD & $\mathrm{M}$ & SD & $\mathrm{M}$ & SD \\
\hline Hypertension $\left(1^{\text {st }} \text { definition }\right)^{*}$ & 0.126 & 0.332 & 0.301 & 0.459 & 0.160 & 0.366 & 0.091 & 0.288 \\
\hline Hypertension ( $2^{\text {nd }}$ definition $)^{*}$ & 0.095 & 0.293 & 0.164 & 0.370 & 0.116 & 0.320 & 0.073 & 0.261 \\
\hline Systolic hypertension (systolic $>=140 \mathrm{mmHG}$ )* & 0.316 & 0.465 & 0.602 & 0.489 & 0.363 & 0.481 & 0.247 & 0.431 \\
\hline Diastolic hypertension (diastolic $>=90 \mathrm{mmHG}$ ) & 0.100 & 0.300 & 0.160 & 0.366 & 0.121 & 0.326 & 0.079 & 0.270 \\
\hline Age finished full-time education & 16.289 & 1.677 & & & & & & \\
\hline Minimum school-leaving age $=15^{*}$ & 0.452 & 0.497 & 0.154 & 0.361 & 0.808 & 0.393 & 0.379 & 0.485 \\
\hline Minimum school-leaving age $=16^{*}$ & 0.352 & 0.477 & 0.024 & 0.155 & 0.100 & 0.300 & 0.531 & 0.499 \\
\hline Age & 49.001 & 16.281 & 68.793 & 10.162 & 53.164 & 11.928 & 43.151 & 14.614 \\
\hline Female* & 0.541 & 0.498 & 0.543 & 0.498 & 0.544 & 0.498 & 0.534 & 0.498 \\
\hline
\end{tabular}

Note: * dummy variable. Hypertension $\left(1^{\text {st }}\right.$ definition $)=1$ if systolic $\mathrm{BP}>=140$ and diastolic $\mathrm{BP}>=90$, and 0 if systolic $\mathrm{BP}<140$ and diastolic $\mathrm{BP}<90$. Hypertension ( $2^{\text {nd }}$ definition) $=1$ if systolic $\mathrm{BP}>=140$ and diastolic $\mathrm{BP}>=90$, and 0 otherwise. The 'hypertension' variables are constructed from the averages of the systolic BP and diastolic BP, which are the mean of the second and third readings in each case, conditioning on these readings being valid. To have any BP reading, HSE respondents had to agree to the nurse visit and agree to have their blood pressure read. For the nurse to classify the reading as valid, the nurse had to be satisfied that, among other things, the respondent did not smoke, drink alcohol or exercise in the 30 minutes preceding the reading. 